\title{
EFFECT OF VITAMIN E AND/OR SELENIUM INJECTION ON: I. REPRODUCTIVE PERFORMANCE OF NEW ZEALAND WHITE AND BALADI BLACK DOE RABBITS UNDER CLIMATE CONDITIONS OF MIDDLE EGYPT
}

\author{
Samia Z. Meshreky and G. H. Metry
}

Animal Production Research Institute, Agricultural Research Center, Giza, Egypt

\section{SUMMARY}

Throughout the period from April to October, 1999 at Seds Research Station, Bani-Suef Governorate (Middle Egypt), 20 of each of New Zealand White (NZW) and Baladi Black (BB) doe rabbits aged 9-10 months old housed in cages under open shed, were randomly divided into four equal groups (each of $5 \mathrm{NZW}$ and $5 \mathrm{BB}$ ), maintained under normal nutritional status. The first group was injected subcutaneously with $100 \mathrm{IU} /$ head/week vitamin $\mathrm{E}$ (Vit E), while the second group was injected intramuscularly with $0.1 \mathrm{mg} / \mathrm{kg}$ body weight/week selenium (Se) as sodium selenite. The third group was injected with Vit E+Se at the same doses of the previous groups. The fourth group was kept as control. The treatments started two weeks before breeding and continued until the fourth parity. Weekly blood samples were collected from marginal ear vein in a heparinized tubes. Maximum and minimum ambient temperature and humidity were measured by digital max.-min. hygro-thermometer.

Temperature-humidity index indicated that the does were exposed to heat stress from April to October. Vitamin $\mathrm{E}$ level in peripheral plasma was higher $(\mathrm{P}<0.001)$ in Vit $\mathrm{E}$ and $\mathrm{Vit} \mathrm{E}+\mathrm{Se}$ groups. Selenium increased significantly $(\mathrm{P}<0.001)$ in plasma of does treated with Se and Vit $\mathrm{E}+\mathrm{Se}$. Does injected with Vit $E$ or Vit $E+S e$ had higher $(P<0.01)$ rectal temperature and respiration rate before mating and during gestation period. Injection with $V$ it $E$ in combination with $S e$ improved $(P<0.01)$ conception rate, litter size at birth, 21 and 28 days old and viability \%, and improved $(\mathrm{P}<0.05)$ bunny weight at birth and 21 days old, while, decreased $(P<0.001)$ abortion \%. Does treated with Vit $E$ or Vit $\mathrm{E}+\mathrm{Se}$ had higher plasma level of progesterone and estradiol $17-\beta$ hormones before mating and during gestation period. The NZW does had higher $(\mathrm{P}<0.05)$ conception rate and litter size at birth, 21 and 28 days old than $\mathrm{BB}$ does. The results suggested that injected NZW and BB doe rabbits with Vit E+Se could alleviate the harmful effect of hot months on their reproductive performance.

Keywords: Rabbit, vitamin E, selenium, reproductive performance

\section{INTRODUCTION}

Conception rate of the doe rabbits appears to be decreased under high ambient temperature (Matassino et al., 1970) due to a complex set of events which expressed as reduction in litter size and increase of still birth. Severe sustained heat stress at $35^{\circ} \mathrm{C}$ reduced the conception rate to $66 \%$ (Shafie et al., 1984), which could be corrected with vitamin and mineral treatments (Marai et al., 1999).

Vitamin E appears to be essential for the integrity and optimum function of the reproductive system (Sheffy and Schultz, 1979). Vitamin E deficiency causes reproductive failure in rabbit (Yamini and stein, 1989), while Vit. E supplementation causes favorable adaptive and better reproductive response of heat-stressed doe (Hassanein et al., 1995).

The role of Se is similar to that of vitamin $\mathrm{E}$ as both are antioxidants (Close, 1999). It is biologically important because it is essential in animal metabolism (Mayland et al., 1989). In addition, combination of $V$ it $E$ and Se have a synergistic effect on enhancement of cell-mediated immunity in rabbit (Liu, 1988) and improved reproduction of the doe rabbit under the hot climate conditions (Abdel-Samee and El-Masry, 1997).

The objective of the present study was to investigate the effect of vitamin $\mathrm{E}$ and / or selenium injection on the reproductive performance of New Zealand White and Baladi Black doe rabbits under hot climate condition of Middle Egypt.

\section{MATERIALS AND METHODS}

This trial was carried out at Seds Research Station, Bani-Suef Governorate (Middle Egypt), belonging to Animal Production Research Institute, Ministry of Agriculture, during the period from April to October, 1999. Twenty of each of New Zealand White (NZW) and Baladi Black (BB) doe rabbits aged 9-10 months old were individually caged in cement pen $(85 \times 60 \times 60 \mathrm{~cm})$ under open 
shed with 6 meters height (the pens were built of two floors above the ground by $60 \mathrm{~cm}$; each of 8 pens,). The does were randomly divided into four equal groups (each of $5 \mathrm{NZW}$ and $5 \mathrm{BB}$ does) maintained under normal nutritional status. The first group was injected subcutaneously with $100 \mathrm{IU}$ vitamin E (Vit E )/ head/ week as dl- $\alpha$ tocopherol acetate (Cairo Company for Medicine, Egypt) dissolved in soybean oil. The second group was injected intramuscularly with $0.1 \mathrm{mg}$ selenium $(\mathrm{Se}) / \mathrm{kg}$ body weight/ week as sodium selenite. The third group was injected with Vit $E+S e$ at the same doses of the previous groups. The fourth group was kept without treatment as a control. The treatments started two weeks before breeding and continued for four consecutive parities. Palpation was performed 10 days after mating to detect pregnancy. Rectal temperature in ${ }^{\circ} \mathrm{C}(\mathrm{RT})$ and respiration rate as breath/min. (RR) were weekly measured between 12:00 and 15:00 hr.

Blood samples from marginal ear vein were collected weekly in a heparinized tubes, centrifuged at 3000 r.p.m. for 15 minutes. Blood plasma was separated and stored at $-20^{\circ} \mathrm{C}$ till analysis. Plasma Vit $\mathrm{E}$ concentration was determined using High Performance Liquid Chromatography (HPLC) and plasma Se concentration was determined using Unicam 929 Atomic Absorption Spectrometer under conditions previously mentioned by Samia-Meshreky and Abbas (2000). Blood plasma progesterone hormone concentration was determined by RIA kits (Diagnostic Systems Laboratories, Inc., USA) according to the manufacturer information. The antiserum had cross reaction values of $100 \%$ with progesterone, $2.5 \%$ with 11-deoxycorticosterone and $0.48 \%$ with 11 -deoxycortisol. The standard curve ranged between 0.0 and $60 \mathrm{ng} / \mathrm{ml}$ and sensitivity value was reported to be $0.12 \mathrm{ng} / \mathrm{ml}$. The intra and inter assay coefficients of variation were found to be 4.8 and $9.2 \%$, respectively. Blood plasma estradiol 17- $\beta$ hormone concentration was determined by RIA kits (Diagnostic Systems Laboratories, Inc., USA) according to the manufacturer information. The antiserum had cross reaction values of $100 \%$ with estradiol and $0.57 \%$ with estriol. The standard curve ranged between 0.0 and $3000 \mathrm{pg} / \mathrm{ml}$ and sensitivity value was reported to be $6.5 \mathrm{pg} / \mathrm{ml}$. The intra and inter assay coefficients of variation were found to be 5.3 and $4.9 \%$, respectively.

Maximum and minimum air temperature $\left({ }^{\circ} \mathrm{C}\right)$, relative humidity $(\%)$ under shed were measured using digital max.-min. hygro-thermometer during the experimental period (Table 1). The temperaturehumidity index (THI) was estimated according to Livestuck and Poultry Heat Stress Indices, Agricultural Engineering Technology Guide, Clemson University, Clemson, Sc 29634, USA, using the following formula: $\mathrm{THI}=\mathrm{db}^{\circ} \mathrm{F}-(0.55-0.55 \mathrm{RH})\left(\mathrm{db}^{\circ} \mathrm{F}-58.00\right)$ where $\mathrm{db}^{\circ} \mathrm{F}=$ dry bulb temperature in Fahrenheit and $\mathrm{RH}=$ relative humidity $(\mathrm{RH} \% \div 100)$. The obtained values of THI were classified as follows: less than $82=$ absence of heat stress, 82 to $<84=$ moderate heat stress, 84 to $<86=$ severe heat stress and those over $86=$ very severe heat stress.

Table 1. Maximum and minimum values of ambient temperature $\left({ }^{\circ} \mathrm{C}\right)$, relative humidity $(\%)$, and temperature-humidity index (THI) in the rabbitry during the experimental period under middle Egypt conditions

\begin{tabular}{lcccccc}
\hline \multirow{2}{*}{ Month } & \multicolumn{2}{l}{$\begin{array}{l}\text { Ambient temperature } \\
\left({ }^{\circ} \mathrm{C}\right)\end{array}$} & \multicolumn{2}{l}{$\begin{array}{l}\text { Relative humidity } \\
(\%)\end{array}$} & \multicolumn{2}{l}{$\begin{array}{l}\text { Temperature } \\
\text { index (THI) }\end{array}$} \\
\cline { 2 - 7 } & Maximum & Minimum & Maximum & Minimum & Maximum & Minimum \\
\hline April & $31.5 \pm 0.6$ & $14.3 \pm 0.4$ & $91.0 \pm 1.1$ & $23.0 \pm 1.0$ & 87.2 & 57.9 \\
May & $36.5 \pm 0.5$ & $20.0 \pm 0.3$ & $87.0 \pm 0.9$ & $23.0 \pm 0.8$ & 94.9 & 63.8 \\
June & $38.4 \pm 0.5$ & $22.8 \pm 0.3$ & $90.0 \pm 0.9$ & $26.0 \pm 0.8$ & 98.8 & 66.9 \\
July & $41.2 \pm 0.4$ & $24.1 \pm 0.2$ & $90.0 \pm 1.0$ & $28.0 \pm 0.9$ & 103.5 & 68.5 \\
August & $41.3 \pm 0.4$ & $24.7 \pm 0.2$ & $91.0 \pm 1.0$ & $30.0 \pm 0.9$ & 103.9 & 69.4 \\
September & $37.7 \pm 0.4$ & $23.6 \pm 0.2$ & $91.0 \pm 1.0$ & $35.0 \pm 0.9$ & 97.8 & 68.6 \\
October & $32.3 \pm 0.4$ & $20.2 \pm 0.2$ & $80.0 \pm 1.0$ & $24.0 \pm 0.9$ & 86.6 & 60.7 \\
\hline
\end{tabular}

The data were analyzed using GLM procedure in SAS ${ }^{\oplus}$ program (1988). The significance of differences among means was evaluated by Duncan's New Multiple Range Test. The following model was used to analyze Vit $\mathrm{E}$ and Se concentrations in blood plasma.

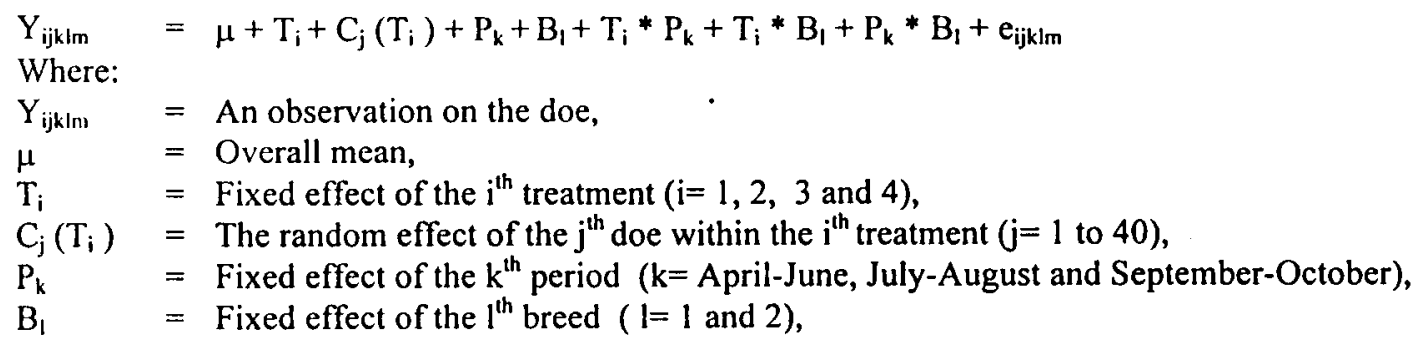


$T_{i}^{*} P_{k}=$ Interaction between the $i^{\text {ih }}$ treatment and $k^{\text {th }}$ period,

$T_{1} * B_{1}=$ Interaction between the $i^{\text {th }}$ treatment and $l^{\text {th }}$ breed,

$\mathrm{P}_{\mathrm{k}}^{*} \mathrm{~B}_{\mathrm{l}}=$ Interaction between the $\mathrm{k}^{\text {th }}$ period and $\mathrm{l}^{\text {th }}$ breed and

$\mathrm{e}_{\mathrm{i} i \mathrm{klm}}=$ The random error.

The following model was used to analyze rectal temperature, respiration rate, reproductive and productive traits, $\mathrm{P} 4$ and $\mathrm{E} 2$ concentrations in blood plasma.

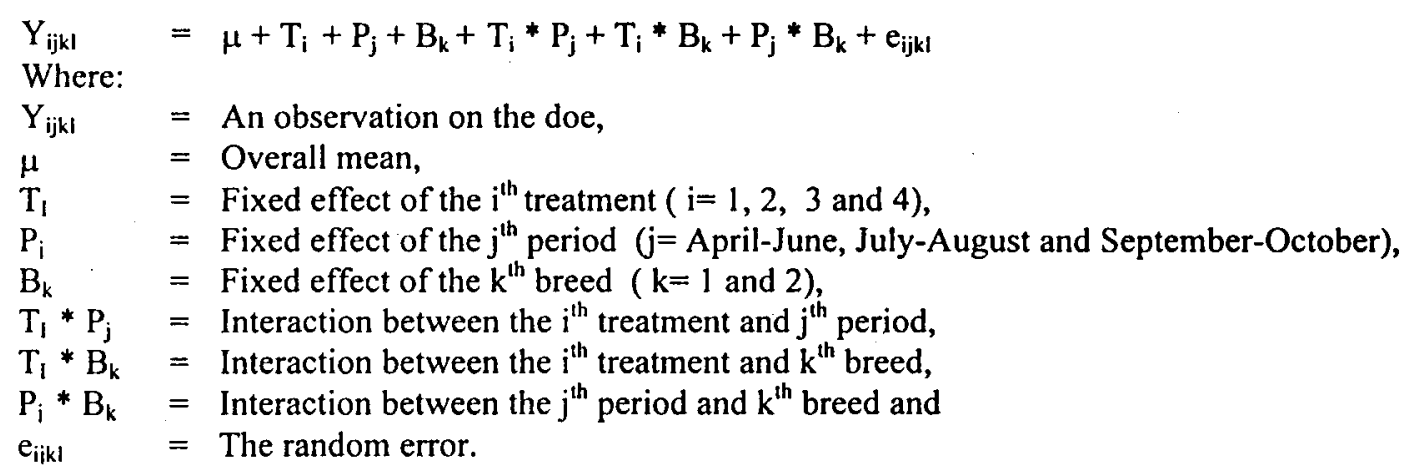

\section{RESULTS AND DISCUSSION}

Temperature-humidity index values were estimated as 87.2 in April and 86.6 in October, indicating exposure of the does to a very severe heat stress (Table 1), with higher values during July and August (103.5 and 103.9). These findings are higher than those reported at East Delta region of Egypt (90.07 and 86.39 during July and August, respectively) by Zeidan et al. (1997).

\section{Blood plasma Vit. E and Se concentrations}

Plasma Vit. E concentration tended to increase $(\mathrm{P}<0.01)$ by advancing post-treatment period (Table 2). These results are within the range of 1.13 and $21.22 \mu \mathrm{g} / \mathrm{ml}$ reported by El-Manyalawi (1995) and higher than 3.67 and $8.21 \mu \mathrm{g} / \mathrm{ml}$ which reported by Castellini et al. (2000). Injection of Vit $\mathrm{E}+\mathrm{Se}$ resulted in an increase $(P<0.001)$ in plasma Vit $E$ level than in the other groups (Table 2 and Figure 1). These findings agree with Verschuren et al. (1990), Lauridsen (1994) and Samia-Meshreky and Abbas (2000). Baladi Black does had higher $(\mathrm{P}<0.05)$ plasma Vit $\mathrm{E}$ level than NZW does (Table 2 ).

Plasma Se level increased $(\mathrm{P}<0.01)$ by advancing post-treatment period (Table 2$)$, which is in consistent with Metry et al. (1998) in buffalo calves, and Samia-Meshreky and Abbas (2000) in rabbit bucks.

Table 2. Vitamin $E(\mu \mathrm{g} / \mathrm{ml})$ and Se $(\mu \mathrm{g} / \mathrm{ml})$ concentrations in blood plasma of rabbit does as affected by post-treatment period, treatment and breed (mean $\pm \mathrm{SE}$ )

\begin{tabular}{|c|c|c|c|c|c|c|c|c|c|}
\hline \multirow[b]{2}{*}{ Item } & \multicolumn{3}{|c|}{ Post-treatment period } & \multicolumn{3}{|c|}{ Treatment } & \multicolumn{3}{|c|}{ Breed } \\
\hline & Apr.-June & Jul.-Aug. & Sep.-Oct. & Vit & Vit E+Se & Control & & $\mathrm{W}$ & $\mathrm{BB}$ \\
\hline & & $* *$ & & & $* * *$ & & & * & \\
\hline $\begin{array}{l}\text { Plasma Vit E } \\
(\mu \mathrm{g} / \mathrm{ml})\end{array}$ & $\begin{array}{c}7.30^{\mathrm{c}} \\
\pm 0.023\end{array}$ & $\begin{array}{c}8.68^{b} \\
\pm 0.023 \\
* *\end{array}$ & $\begin{array}{r}10.53^{\mathrm{a}} \\
\pm 0.023\end{array}$ & $\begin{array}{l}14.02^{b} \\
\pm 0.024\end{array}$ & $\begin{array}{c}2.80^{c} \\
\pm 0.024 \\
* * *\end{array}$ & $\begin{array}{c}16.7^{\mathrm{a}} \\
\pm 0.024\end{array}$ & $\begin{array}{c}1.82^{d} \\
\pm 0.024\end{array}$ & $\begin{array}{c}8.57^{\mathrm{b}} \\
\pm 0.017 \\
\mathrm{NS}\end{array}$ & $\begin{array}{c}9.10^{\mathrm{a}} \\
\pm 0.017\end{array}$ \\
\hline $\begin{array}{c}\text { Plasma Se } \\
(\mu \mathrm{g} / \mathrm{ml})\end{array}$ & $\begin{array}{r}0.032^{\mathrm{c}} \\
\pm .0003\end{array}$ & $\begin{array}{r}0.036^{\mathrm{b}} \\
\pm .0003\end{array}$ & $\begin{array}{r}0.042^{a} \\
\pm .0003\end{array}$ & $\begin{array}{l}0.027^{\mathfrak{c}} \\
\pm .0003\end{array}$ & $\begin{array}{l}0.044^{b} \\
\pm .0003\end{array}$ & $\begin{array}{r}0.055^{\mathrm{a}} \\
\pm .0003\end{array}$ & $\begin{array}{l}0.021^{d} \\
\pm .0003\end{array}$ & $\begin{array}{c}.0368^{\mathrm{a}} \\
\pm .0002 \\
\end{array}$ & $\begin{array}{r}.0363^{\mathrm{a}} \\
\pm .0002\end{array}$ \\
\hline
\end{tabular}

$*(\mathrm{P}<0.05) . \quad * *(\mathrm{P}<0.01) . \quad * * * \quad(\mathrm{P}<0.001) . \quad$ NS $=$ Nonsignificant.

a,b,c,d Values with different superscripts within the same row are significantly different $(\mathrm{P}<0.05)$. 

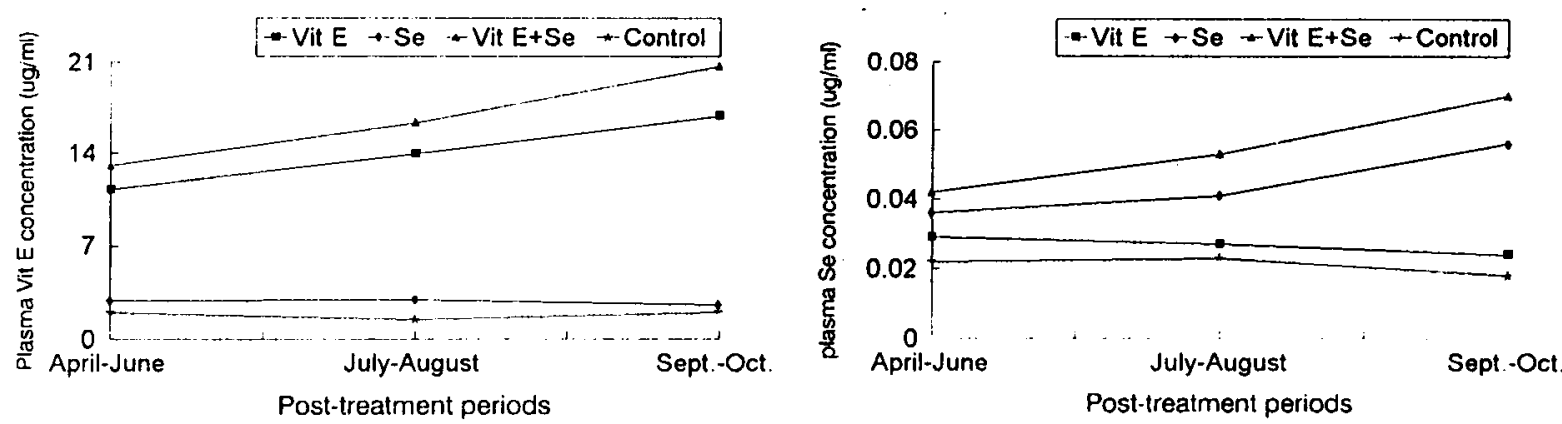

Figure 1. Plasma Vit $\mathrm{E}$ and Se concentration in rabbit does, during post-treatment period.

The does injected with Vit $\mathrm{E}+\mathrm{Se}$ had higher $(\mathrm{P}<0.001)$ plasma Se level than those treated with Se alone (Table 2 and Figure 1). These results are in accordance with those reported by Stowe and Herdt (1992) and El-Gaafarawy et al. (2000).

\section{Thermoregulatory responses}

Increase in ambient temperature during the experimental periods (April-October) caused an increase in $R T(P<0.05)$ and $R R(P<0.01)$ before mating $(B M)$. mid gestation $(M G)$ and during the last week of gestation (LG) as shown in Table 3. These findings agree with Sedki (1999) and Habecb et al. (1999). Does treated with Vit $E$ and Vit $E+S e$ had higher $(P<0.01)$ RT and RR than the other groups during BM, MG and LG periods (Table 3). These results agree with Hassanein et al. (1995), reporting increase of $\mathrm{RT}$ and $\mathrm{RR}$ by advancing stages of gestation.

The NZW does had higher RT and RR than the BB does during gestation period (Table 3). The interaction between periods of the experiment and treatments was significant $(P<0.01)$ for $R T$ and $R R$. The does treated with Vit E or Vit E+Se had higher RT and RR during the different periods than the other groups. This might be due to the positive correlation between RT and plasma concentration of Vit E (Amici and Merendino, 1996). The interaction between treatment and breed was significant $(\mathrm{P}<0.05)$ for RT and RR at BM, MG and LG. Treated NZW does with Vit $E$ or Vit $E+S e$ had higher $\mathrm{RT}$ and RR than BB treated does. This might be due to that $\mathrm{BB}$ does are more adaptive to the hot climate than NZW does.

Table 3. Rectal temperature (RT) and respiration rate (RR) before mating (BM), mid gestation (MG) and last week of gestation (LG) of rabbit does as affected by post-treatment periods, treatment and breed (mean $\pm \mathrm{SE}$ ).

\begin{tabular}{|c|c|c|c|c|c|c|}
\hline \multirow[b]{2}{*}{ Item } & \multicolumn{3}{|c|}{$\mathrm{RT}\left({ }^{\circ} \mathrm{C}\right)$} & \multicolumn{3}{|c|}{$\mathrm{RR}$ (breath/min.) } \\
\hline & $\mathrm{BM}$ & MG & LG & $\mathrm{BM}$ & MG & LG \\
\hline Overall mean & $39.4 \pm .112$ & $39.6 \pm .114$ & $39.9 \pm .137$ & $165.5 \pm 2.26$ & $174.8 \pm 2.27$ & $187.5 \pm 1.75$ \\
\hline Period : & $*$ & * & $* *$ & ** & $* *$ & ** \\
\hline April-June & $39.2 \pm .023^{\mathrm{b}}$ & $39.5 \pm .023^{b}$ & $39.7 \pm .028^{\mathrm{b}}$ & $152.8 \pm .46^{\mathrm{c}}$ & $158.1 \pm .46^{\mathrm{c}}$ & $173.5 \pm .34^{c}$ \\
\hline July-August & $39.5 \pm .023^{\mathrm{a}}$ & $39.7 \pm .023^{8}$ & $40.2 \pm .028^{\mathrm{a}}$ & $169.0 \pm .46^{\mathrm{b}}$ & $187.3 \pm .46^{\mathrm{a}}$ & $200.8 \pm .34^{\mathrm{a}}$ \\
\hline Sept.-October & $39.4 \pm .023^{\mathrm{a}}$ & $39.6 \pm .023^{a}$ & $39.8 \pm .028^{b}$ & $174.8 \pm .46^{\prime \prime}$ & $179.1 \pm .46^{\mathrm{b}}$ & $188.2 \pm .34^{b}$ \\
\hline Treatment: & ** & ** & $* *$ & $* *$ & $* *$ & $* *$ \\
\hline Vit E & $39.6 \pm .026^{\mathrm{a}}$ & $39.8 \pm .027^{\mathrm{a}}$ & $40.1 \pm .032^{\mathrm{a}}$ & $169.8 \pm .53^{b}$ & $180.8 \pm .54^{\mathrm{ab}}$ & $192.7 \pm .54^{\mathrm{a}}$ \\
\hline $\mathrm{Se}$ & $39.3 \pm .026^{b}$ & $39.4 \pm .027^{b}$ & $39.6 \pm .032^{\mathrm{c}}$ & $160.2 \pm .53^{b}$ & $171.8 \pm .54^{\mathrm{b}}$ & $177.2 \pm .54^{\mathrm{b}}$ \\
\hline Vit $E+S e$ & $39.5 \pm .026^{\mathrm{a}}$ & $39.7 \pm .027^{\mathrm{a}}$ & $40.0 \pm .032^{\mathrm{a}}$ & $183.7 \pm .53^{\mathrm{a}}$ & $187.5 \pm .54^{\mathrm{a}}$ & $198.8 \pm .54^{\mathrm{a}}$ \\
\hline Control & $39.2 \pm .026^{\mathrm{b}}$ & $39.5 \pm .027^{b}$ & $39.8 \pm .032^{\mathrm{b}}$ & $148.5 \pm .53^{c}$ & $159.2 \pm .54^{c}$ & $181.5 \pm .54^{b}$ \\
\hline Breed: & NS & $*$ & $* *$ & * & * & * \\
\hline NZW & $39.5 \pm .018^{\mathrm{a}}$ & $39.7 \pm .019^{a}$ & $40.1 \pm .023^{\circ}$ & $173.2 \pm .38^{\mathrm{a}}$ & $181.2 \pm .38^{\mathrm{a}}$ & $194.3 \pm .29^{\mathrm{a}}$ \\
\hline $\mathrm{BB}$ & $39.3 \pm .018^{\mathrm{a}}$ & $39.4 \pm .019^{b}$ & $39.6 \pm .023^{\mathrm{b}}$ & $157.9 \pm .38^{\mathrm{b}}$ & $168.5 \pm .38^{b}$ & $180.9 \pm .29^{b}$ \\
\hline
\end{tabular}

Reproductive traits

Periods of the experiment had a significant effect on conception rate, abortion $\%$ gestation length, litter size at birth, 21 and 28 days old, and bunny weight at 21 and 28 days old (Table 4). Armstrong et al. (1993) reported that reproduction of animals is impaired as a results of the drastic changes in biological functions caused by heat stress. In this study, viability (\%) from birth to 21 and 
28 days old was higher $(\mathrm{P}<0.05)$ for bunnies born in September-October than the other two periods (Table 4). Similar trend was reported by Sedki (1999).

The does injected with Vit. E+Se or Vit. E alone gave the best values for the most reproductive traits (Table 4). The higher litter size obtained at birth from the does injected with Vit. E+Se might be related to the increase in ovulation and fertilization rates (Abdel-Samee and El-Masry, 1997 and Shetaewi, 1998). The Vit. E+Se and Vit. E alone injection decreased $(\mathrm{P}<0.001)$ abortion (\%). This finding is confirmed by Yamini and Stein (1989) who noticed that Vit. E deficiency caused an increase in abortion \% in rabbits. Also, The Vit. $\mathrm{E}+\mathrm{Se}$ and Vit $\mathrm{E}$ alone injection increased $(\mathrm{P}<0.01)$ viability (\%) of the bunnies from birth to 21 and 28 days old (Table 4). This result agrecs with Ismail (1993) and Hassanein et al. (1995). Reddy et al. (1987) attributed the reduction of mortality rate as a result of Vit. E treatment to the increase in immunity response. Does injected with Sc alone improved slightly some reproductive traits than control group (Table 4).

New Zealand White does showed higher $(P<0.05)$ conception rate, litter size at birth, 21 and 28 days old, higher $(\mathrm{P}<0.01)$ bunny weight at birth and 28 days old than Baladi Black does (Table 4$)$. These results are in accordance with Marai (1999). However, Soad-Ahmed and Marai (1998) found that Baladi Black breed had higher litter size at birth and litter weight at 21 days old than NZW breed.

The interaction between periods of experiment and treatments was significant $(\mathrm{P}<0.01)$ for conception rate, abortion \% and litter size at birth, 21 and 28 days old, and $(\mathrm{P}<0.05)$ for bunny weight at birth, 21 and 28 days old and viability \% from birth to 21 and 28 days old. The interaction between treatments and breeds was significant $(\mathrm{P}<0.05)$ for reproductive and productive traits. Injected NZW does with $V i t E$ or $V i t ~ E+S e$ resulted in an improve of reproductive and productive traits than $B B$ treated does. This might be due to that NZW responded more efficiently to the treatment than BB does. The interaction between breed and experimental period was significant $(\mathrm{P}<0.05)$ for reproductive traits and $(\mathrm{P}<0.01)$ for bunny weight at birth, 21 and 28 days old.

\section{Hormonal pattern secretion}

\section{Progesterone hormone $\left(\mathbf{P}_{4}\right)$}

During April-June period, plasma $\mathrm{P} 4$ level was higher $(\mathrm{P}<0.01)$ before mating and during gestation puriod than in September-October, and the lowest $\mathrm{P} 4$ value was recorded during the hottest months (July-August), (Table 5). Bohr and Dial (1982) suggested that the lower P4 level in hot months might be due to indirect effect of increase ambient temperature that leads to fluctuation in LH level, which has primary stimulating effect on P4 secretion in domestic animals (Revecs, 1980).

Before mating and during gestation period, does injected with Vit E+Se maintained higher $(\mathrm{P}<0.001)$ or $(\mathrm{P}<0.01) \mathrm{P} 4$ level followed by those injected with Vit $\mathrm{E}$ than Se and control groups (Table 5 and Figure 2). Such higher $\mathrm{P} 4$ values can be attributed to increase in ovulation rate (Habeeb and El-Masry, 1991). On day-7 of gestation, the plasma P4 level increased and continued till day-14, then declined towered day-21 and continued till day-28 of gestation (Figure 2). Karousa et al. (1999) found that $\mathrm{P} 4$ levels were 0.6 and $16.3 \mathrm{ng} / \mathrm{ml}$ at mating and day-10 after mating for NZW rabbits.

Baladi Black does maintained higher $(\mathrm{P}<0.05) \mathrm{P} 4$ level on the day-14 and day- 21 of gestation than NZW does (Table 5). Hassanein et al. (1995) found that Baladi Red does had higher P4 level than $\mathrm{NZW}$. In this study the average P4 level for NZW does before mating $(0.50 \mathrm{ng} / \mathrm{ml})$ is higher than 0.38 $\mathrm{ng} / \mathrm{ml}$ as reported by Khalil and El-Sharabassy (1987).

The interaction between periods of the experiment and treatments was significant $(P<0.01)$ for $P 4$ level. Vitamin $E$ or Vit $\mathrm{E}+\mathrm{Se}$ injection tended to increase $\mathrm{P} 4$ level during different periods of the experiment than the does treated with Se or control group. The interaction between periods and breeds was significant $(\mathrm{P}<0.05)$ for $\mathrm{P} 4$ level at $\mathrm{BM}$ and 28 days of gestation, and $(\mathrm{P}<0.01)$ at 7 and 14 days of gestation. Baladi Black does had higher $\mathrm{P} 4$ level than NZW does during April-June and SeptemberOctober periods

\section{Estradiol 17-ß hormone (E2)}

Plasma E2 levels were higher $(\mathrm{P}<0.01)$ during April-June followed by September-October and the lowest values were recorded in July-August (hottest months), before mating, at day- 7 and day- 28 of gestation (Table 5). This indicated that increased ambient temperature, decreased E2 hormone secretion. 


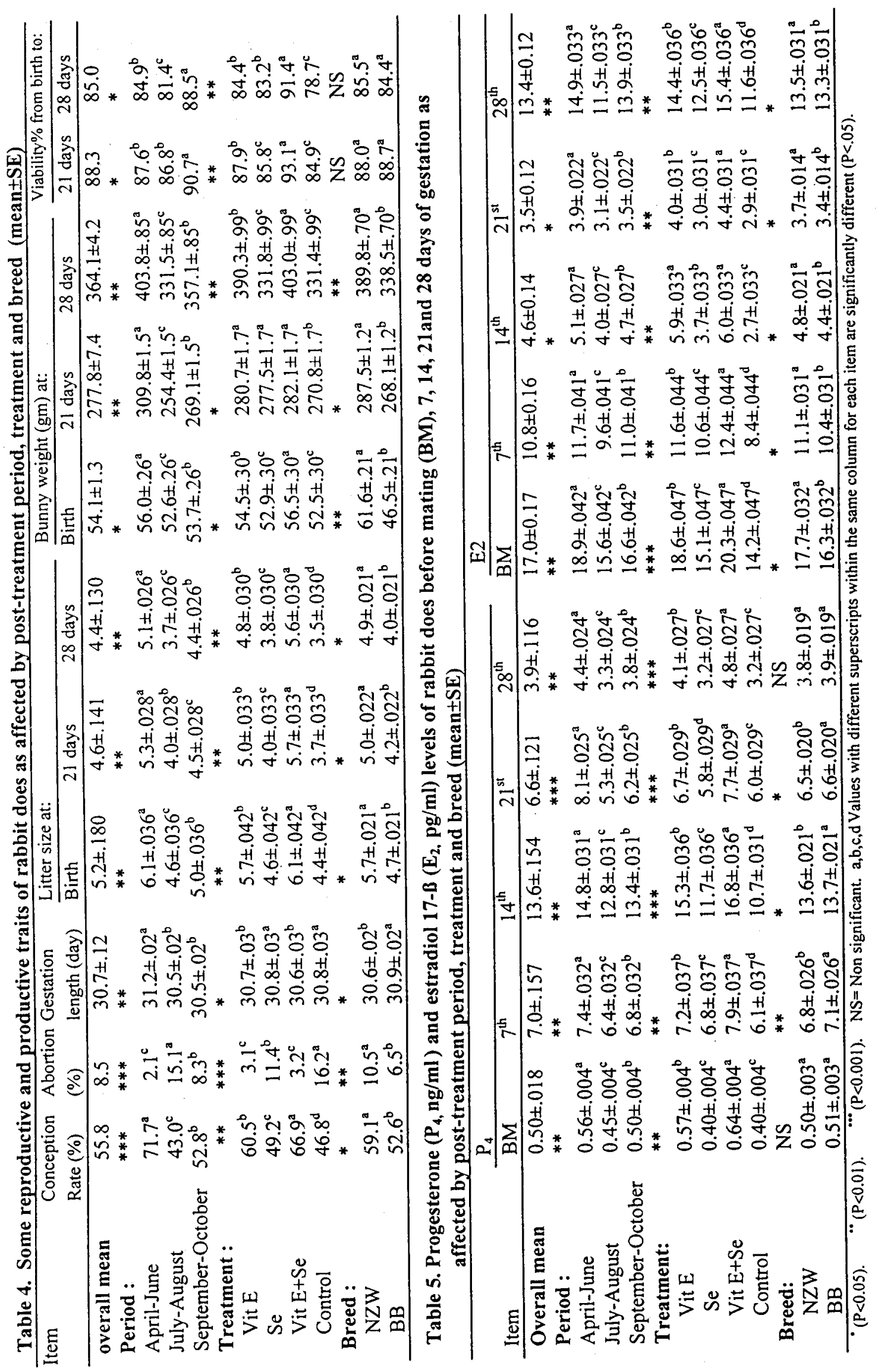


Does injected with Vit. E+Se and Vit. E alone had higher $(\mathrm{P}<0.01) \mathrm{E} 2$ level than Se and control groups. The pattern of $\mathrm{E} 2$ secretion was high before mating, on day-7 and day-28 of gestation (Table 5 and Figure 2). Stoufflet and Caillol (1988) and Kishk et al. (1999) reported that the pattern of E2 secretion shortly before mating as for receptive does. Karousa et al. (1999) found that E2 levels were 15.8 and $12.1 \mathrm{pg} / \mathrm{ml}$ at mating and day-10 after mating for NZW rabbits. Stormshak and Casida (1965) observed high level of E2 during the first seven days of pregnancy in order to maintain function of corpus luteum.
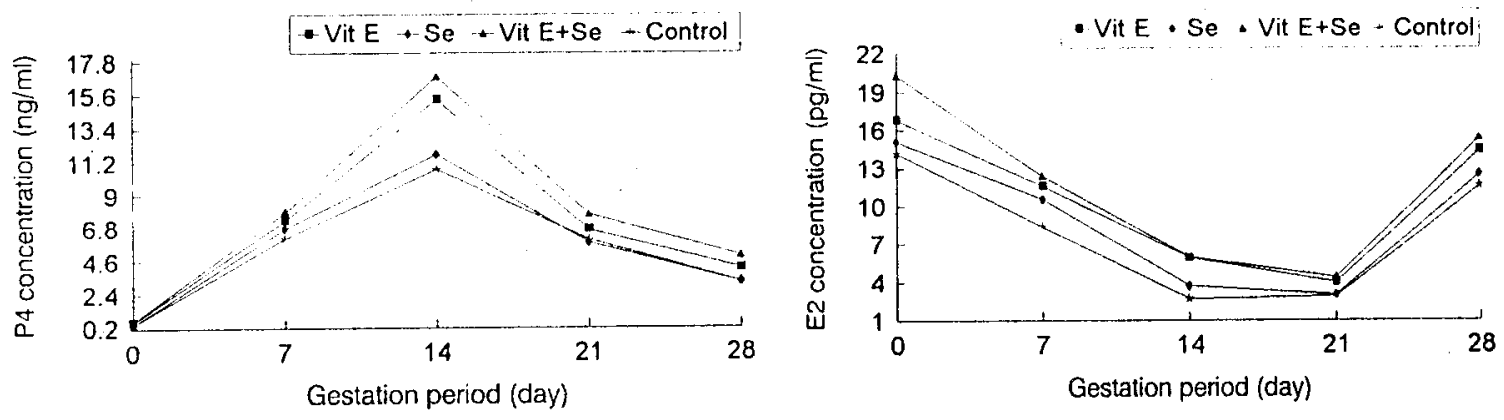

Figure 2. Patterns of circulating $\mathrm{P4}$ and $\mathrm{E} 2$ concentration in peripheral plasma of does before mating and during gestation period.

The NZW does had higher $(\mathrm{P}<0.05)$ E2 levels before mating and during gestation period than Baladi Black does (Table 5). The interaction between periods of the experiment and treatments was significant $(P<0.05)$ for $E 2$ level. Vitamin $E$ or Vit $E+S e$ injection tended to increase $E 2$ level during different periods of the experiment than the does treated with Se or control group. The interaction between treatments and breeds was significant $(\mathrm{P}<0.05)$ for $\mathrm{E} 2$ level. The NZW treated does had higher E2 level than BB treated does. This might be due to the effect of Vit $E$ or Vit $E+S e$ injection that increased the number of graafian follicles presented on the ovaries of NZW does.

\section{CONCLUSION}

It could be concluded that injected NZW and BB doe rabbits with Vit E+Se could alleviate the hurmful effect of severe hot months on their reproductive performance.

\section{REFERENCES}

Abdel-Samce, A. M. and K. A. El-Masry, 1997. Effects of varying copper levels or selenium with vitamin E supplementation on growth and reproductive performance of New Zealand While rabbits under subtropical conditions. Egyptian Poult. Sci., 17: 133-149.

Amici, A. and N. Merendino, 1996. Some metabolic and immunological parameters in rabbits as affected by prolonged thermal stress. $6^{\text {th }}$ World Rabbit Congress, Toulouse, 2: 147-150.

Armstrong, D. V.. W. T. Welchert, F. Wiersma. E. Collins and C. Boon. 1993. Environmental modification for dairy cattle housing in arid climates. Livestock Environment IV. Proceedings of a Conference held in Coventry, UK, 1223-1233.

Bohr, J. M. and O. K. Dial, 1982. Effect of day length on reproductive hormones in domestic rabbits. J. Appl. Rabbit Res., 5: 6-7.

Castellini, C., A. Dal Bosco and M., Bernardini, 2000. Effect of dietary $\alpha$ tocopherol acetate and ascorbic acid: vitamin content and oxidation status of rabbit semen. $7^{\text {th }}$ World Rabbit congress 4-7 July, Valencia, Spain. Vol: A, pp 105-110.

Close, W. H., 1999. Organic minerals for pigs: An update. Proceeding of Our Industry Under the Microscope. Biotechnology responds. Alltech's European, Middle Eastern and African Lecture Tour.

El-Gaafarawy. A. M., Nagwa ahmed, M. K. El-Banna and I. L. Ibrahim. 2000. Effects of selenium and vitamin E supplementation on immune response and performance of Balady calves. Conference on Animal Production in the Twenty First Century Challenges and Prospects. Abstracts, Sakha, Kafr El-Skeikh, Egypt.

El-Manyalawi, M. A. F. M., 1995. Response of rabbit performance to dietary vitamin A and/or vitamin E. M. Sc. Thesis, Faculty of Agriculture. Cairo, University, Egypt. 
Habeeb, A. A. M. and K. A. El-Masry, 1991. Hormonal pattern in pregnant rabbits and some productive aspects as affected by litter size at birth. Egypt. Poult. Sci., 11:429.

Habeeb, A. A. M., A. M. El-Maghawry, I. F. M. Marai and A. E. G. Gad, 1999. Interaction effects between drinking saline water and ambient temperature on T3. survival ratc. kidney function and some productive traits in two breeds of acclimatized rabbits. $1^{\text {s1 }}$ International Conference on Indigenous Versus Acclimatized Rabbit, El Arish, North Sinai, Egypt.

Hassancin, A. M., G. Ashour, H. M. Gad, and A. M. Saced, 1995. Adaptive and reproductive performance of rabbits. 3. Role of vitamin $E$ in environmental adaptation. Egyptian Journal of Animal Production, 32: 91- 102.

Ismail, A. M., 1993. Effect of feeding different levels of some vitamins on reproductive performance of heat stressed pregnant femalc rabbits. Ph. D. Thesis, Fac. Agric. Ain-Shams University, Egypt.

Karousa, M. M., E. A. Mahmoud and I. S. Meneeh, 1999. Effect of mating type on reproductive traits in New Zealand White rabbits. Egyptian J. Rabbit Sci., 9: 105-116.

Khalil, F. A. and A. A. M. El-Sharabassy, 1987. Peripheral progesterone profile in the pregnant Californian rabbits. Al-azhar J. Agric. Res. 8.

Kishk. W. H., E. G. Alıncd. A. M. Abdl-Ghany, M. M. Awad. A. A. Osman and A. A Amin.. 1999. The relationship among ovarian steroid hormones, litter and milk traits of New Zealand White and Californian rabbits. $1^{\text {st }}$ International Conference on Indigenous vs. Acclimatization rabbits, ElArish, North Sinai, Egypt.

Lauridsen. A. M., 1994. The influence of dietary synthetic antioxidants (ethoxyquin and Butylhydroxytoluene) on broilcrs. M. Sc. Thesis, The Royal Veterinary and Agricultural University. Copenhagen, Denmark.

Liu, Z. P., 1988. Effects of sclenium on cell-mediated immunity in rabbits. Chinese Journal of Veterinary Science and Technology, 8: 17-19.

Marai, I. F. M., 1999. Indigenous versus imported rabbit in Egypt. ${ }^{\text {st }}$ International Conference on Indigenous Versus Acclimatized Rabbit. El Arish, North Sinai, Egypt. pp 1-5.

Marai, I. F. M., M. S. Ayyat, H. A. Gabr, and U. M. Abd El-Monem, 1999. Growth performance. some blood metabolites and carcass traits of New Zealand White broiler male rabbits as affected by heat stress and its alleviation, under Egyptian conditions. Cahiers Options Mediterranean's, 41: $35-42$.

Matassino, D., A. Bordi and A. Nardone, 1970. Some vital statistics of the native improved breed of rabbit. Produzione Animale. 9: 21-25.

Mayland, H. F., L. F. James, K. E. Panter and J. L. Sondergger, 1989. Selenium in seleniferous environments. Soil Science Society of Amcrican and American Society of Agronomy, 2:15-47.

Metry, G. H., R. H. Youssef and R. M. Khattab, 1998. Studies on selenium and/or vitamin E administration to Egyptian buffalo calves. I. Effect on blood serum selenium level, daily gain and some blood constituents. Egyptian Journal of Animal Production. 35: (Supplement) 451-465.

Reddy. P. G.. L. Morrill and R. A. Fery. 1987. Vitamin E requirements of dairy calves. J. Dairy Sci. 70: $123-130$.

Revees, J. J., 1980. Endocrinology of Reproduction in: Reproduction of Farm Animals. B. Tindall. (Ed), Lee and Febiger London, UK.

Samia-Meshreky, Z. and H. E. Abbas, 2000. Efficiency of vitamin E and selenium injection on improving reproductive performance of male rabbits under hot climatic conditions of middle Egypt. In the Proc. of Future Aspects for Agricultural and Social development, El-Arish, Sinai, Egypt.

SAS ${ }^{\circledR}, 1988$. User's Guide: Statistics, Version 6.03 Edition. SAS inst. Inc., Cary, NC.

Sedki, A. A., 1999. Effect of different housing systems on rabbits performance. Ph. D. Thesis, Faculty Agriculture, Cairo University, Cairo, Egypt.

Shafie, M. M., G. A. R. Kamar, A. H. A. Borady and A. M. Hassanein, 1984. Reproductive performance of Giza rabbil does under different natural and artificial environmental condition. Egyptian J. Animal Production, 24: 167-174.

Sheffy, B. E. and R. D. Schultz, 1979. Influence of vitamin $E$ and selenium on immune response mechanism. Fed. Prod., 38: 2139.

Shetaewi, M. M., 1998. Effects of dietary supplemental vitamin $E$ on reproduction, growth and carcass traits of rabbits. Egypt. J. Nut. And Feeds, 1: 87-96.

Soad-Ahmed, S. and I. F. M. Marai, 1998. Milk yield and litter traits of rabbits as affected by breed, parity, number of nipples and aminazine injection, under Egyptian sub-tropical conditions. $1^{\text {st }}$ International Conference on Indigenous Versus Acclimatized Rabbit, El Arish, North Sinai, Egypt. pp 407-415. 
Stormshak, F. and L. H. Casida, 1965. Effects of LH and ovarian hormones on corpora lutea of pseudopregnant and pregnant rabbits. Endocrinology, 77: 337-342.

Stoufflet, I. and M. Caillol, 1988. Relations between circulating sex steroid concentrations and sexual behavior during pregnancy and post partum in the domestic rabbit. J. Rep. Fert., 82: 209-218.

Stowe, H. D. and T. H. Herdt, 1992. Clinical assessment of sclenium status of livestock. Journal of Animal Science, 70: 3928-3938.

Verschuren, P. M., U. M. T. Houtsmuller and Jr. Zevenbergen, 1990. Evaluation of vitamin E requirement and food palatability in rabbits fed a purified diet with a high fish oil content. Unilever Research Laboratorium Vlaardingen, Netherlands. Laboratory- Animals. 24: (2): 164-171.

Yamini, B. and S. Stein, 1989. Abortion, stillbirth, neonatal death and nutritional myodegeneration in rabbit colony. J. Amer. Vet. Med. Assoc., 194: 561-562.

Zcidan, A. E. B., I. F. M. Marai, M. A. Abd El-Kariem and Z. A. Ibrahim, 1997. Effects of intratesticular injection of gonadotropin releasing hormone on reproductive performance of low fertile malc rabbits, under Egyptian summer condition. Procecding Internalional Conference on Animal, Poultry, Rabbit Production and Health. Dokki. Egypt. pp 557-566. 